\title{
Major-surface-protein-4-gene-based detection of Anaplasma marginale isolated from sheep in Al-Diwaniyah province, Iraq
}

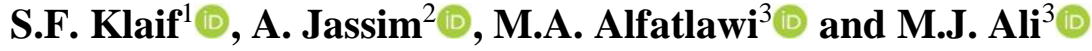 \\ ${ }^{1}$ Unit of Zoonotic Disease Research, Department of Internal Medicine, ${ }^{2}$ Department of Veterinary Microbiology, ${ }^{3}$ Department \\ of Veterinary Microbiology, College of Veterinary Medicine, University of Al-Qadisiyah, Al-Diwaniyah, Iraq
}

\begin{tabular}{l} 
Article information \\
\hline Article history: \\
Received December 26, 2020 \\
Accepted March 21, 2021 \\
Available online November 8, 2021 \\
\hline Keywords: \\
Anaplasma marginale \\
Major surface protein \\
Al-Diwaniyah \\
Iraq \\
\\
\hline Correspondence: \\
M.A. Alfatlawi \\
monyerr.abd@ @u.edu.iq
\end{tabular}

\begin{abstract}
This study was purposed for confirming detection and typing of Anaplasma spp in infected sheep from Al-Diwaniyah province, Iraq. Sampling of 50 blood specimens was performed from clinically-identified infection of anaplasmosis. The samples of the blood were subjected to DNA extraction followed by polymerase-chain-reaction (PCR)-based detection of the Anaplasma marginale using major surface protein (MSP4) gene. The results have shown that 8 blood samples were infected with A. marginale. The PCR-based identification has revealed a confirmative identification of the Anaplasma marginale in the infected sheep. The study identifies Anaplasma marginale as a member of infectious agents that affect sheep in the study city.
\end{abstract}

DOI: 10.33899/ijvs.2021.129230.1635, (CAuthors, 2022, College of Veterinary Medicine, University of Mosul.

This is an open access article under the CC BY 4.0 license (http://creativecommons.org/licenses/by/4.0/).

\section{Introduction}

Anaplasmosis infection is one of the major disease conditions that affect ruminants in the world, and Anaplasma marginale is appreciated to be one of the biological-infectious agents that affect health of animals plus increase economic crisis in the affected areas $(1,2)$. This tick-borne disease is responsible of high mortality rates in the infected animals (3-7). With an incubation period that could reach up to 60 days, signs of severe anemia in the affected animals are manifested due to engulfing of the Anaplasma-infected erythrocytes in the reticuloendothelial system (8). The disease is characterized by the appearance of fever, paleness, anorexia, lethargy, and icterus $(9,10)$. At the level of tissue changes, anaplasmosis induces several alterations such as hepatic and splenic degeneration as a result to anemia and decreased levels of oxygen plus deposition of high amounts of the destructed-erythrocyte-based pigments in the spleen (10). In Iraq, anaplasmosis causes a great impact on the herds and livestock, and using ordinary-diagnostic techniques, such as blood visualization using microscopes, generates low-quality identification of the tested cases (1113). The disease treatment and control are challenging and required long and frequent testing of the suspected animals using specific and new tools. Here, PCR was used to identify these infections and recognize the main infectious Anaplasma spp that affects sheep in Al-Diwaniyah, Iraq.

\section{Materials and methods}

This study was purposed for confirming detection and typing of Anaplasma spp in infected sheep from AlDiwaniyah province, Iraq. 50 Blood samples of sheep were collected from clinically-identified infection of anaplasmosis. These blood samples were collected in anticoagulant-based tubes. After that, they were kept in a Lab fridge waiting for the next processing steps of this study. The samples of the blood were subjected to DNA extraction followed by polymerase-chain-reaction (PCR)- 
based detection of the Anaplasma marginale using major surface protein (MSP4) gene.

\section{DNA extraction}

To complete the detection process, the 50-blood samples were exposed to commercial-kit-based extraction of the genomic DNA using Genomic DNA Mini Kit ${ }^{\circledR}$ (Geneaid, China). The manufacturer's information provided with kit was followed to complete this step. Frozen-blood and proteinase- $\mathrm{K}$ type of extraction was performed. The DNA resulted from this process was subjected to NanoDrop spectrophotometer to estimate it quality and quantity. Then, DNA was kept stored at $-20^{\circ} \mathrm{C}$ to follow up with the next steps.

\section{Polymerase chain reaction \\ Relying on specific primers which designed by authors by using Gene bank data base, F: ACGAAGTGGCTTCTGAAGGG and R:} AGCTAATCCCAACCTTGCCC, PCR was assigned to amplify a highly-conserved sequence of nucleotides, 567bp, in the MSP4 gene that belongs to A. marginale. Bioneer Company, South Korea was ordered to purchase these primers. The mastermix reaction recipe was followed utilizing AccuPower ${ }^{\circledR}$ PCR PreMix kit (Bioneer Comp. South Korea). DNA polymerase 1U, dNTPs $250 \mu \mathrm{M}$, Tris$\mathrm{HCl}(\mathrm{pH} 9.0) 10 \mathrm{mM}, \mathrm{KCl} 30 \mathrm{mM}, \mathrm{MgCl} 21.5 \mathrm{mM}$, stabilizer, and tracking dye were already provided in the mastermix tubes. The information accompanied with kit was used to initiate the process of preparing this reaction recipe. After that, adding one by one of $5 \mu 1$ DNA, $1.5 \mu 1$ of 10 pmole of each primer, and $12 \mu \mathrm{l}$ PCR water was completed. Brief vortexing and centrifugation followed the addition of these components. Then, a thermocycler (Eppendorff Company. Germany) was used to generate the processes of the PCR reaction. The conditions of the thermocycler used in this step were initial denaturation temperature of $95^{\circ} \mathrm{C}$ for $5 \mathrm{~min}, 30$ cycles of the denaturation $95^{\circ} \mathrm{C}$ for 1 minute, annealing $58^{\circ} \mathrm{C}$ for $1 \mathrm{~m}$, and extension $72^{\circ} \mathrm{C}$ for $1 \mathrm{~m}$, and final extension at $72^{\circ} \mathrm{C}$ for 10 min. Electrophoresis via the use of ethidium-bromidetreated $1.5 \%$-agarose gel was performed to visualized the PCR products under a UV illuminator.

\section{Results}

\section{Clinical examination results}

In mild signs, infected sheep showed signs of pale mucus membranes, loss of appetite and weight loss. Although in light infestation with ticks, these sheep were having a signs of fever.

\section{Microscopic results}

Intracytoplasmic Anaplasma inclusion bodies were visualized in erythrocytes.

\section{PCR results}

The results have shown that 8 out of 50 blood samples were infected with A. marginale. The PCR-based identification has revealed a confirmative identification of the Anaplasma marginale in the infected sheep. The amplification of the 567-bp piece of the MSP4 gene that belongs to A. marginale was successfully generated (Figure 1).

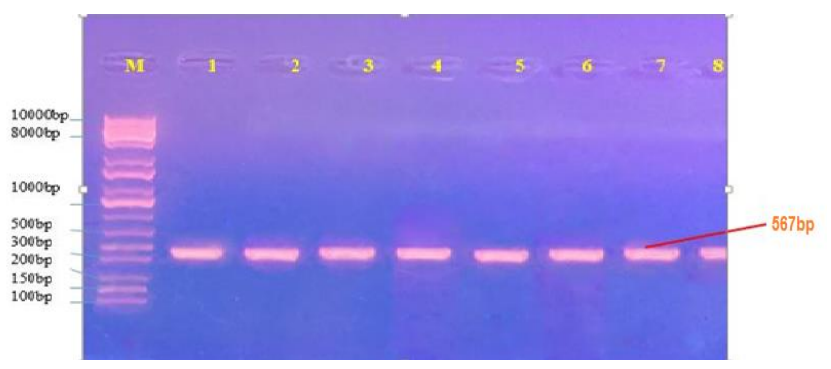

Figure 1: Image of the electrophoresis of Anaplasma marginale that demonstrates the PCR product amplification of 567-bp piece that belongs to the MSP4 gene. Lane M is the ladder, 100bp. Lane 1 to 8 are the positive amplified products.

\section{Discussion}

The ticks which transmit a wide range of veterinary important pathogens, are hyperendemic in the middle and south of Iraq (14). In Iraq, Recent studies of A. ovis and A. marginale in Al-Qadisiyah province, Al-Nasiriyah city and Duhok province were detected in significant infection rate in cattle, sheep and goat respectively (15-17). The most clinical signs which observed by clinical examination on infected sheep were agreed with Ayyz et al. (15). Microscopic examination it's insufficient to detect the low level of Anaplasma infection (18-20), so that molecular methods used for detecting the undetected cases of infected animals $(21,22)$. Using of the PCR technique for more specific and sensitive detecting of minimum level of Anaplasma in infected animals (23-26).

The results of the PCR technique have confirmed that 8 sheep were infected with A. marginale. The rest of the 42 sheep might have been infected with different infectious agents. However, the results indicate that the sheep in the sampled city are suffered from the infection of this species of Anaplasma spp. Moreover, these results also confirm the PCR reliability to identify $A$. marginale from clinical samples, were Gale et al. (27) who compared the results of PCR and ELISA techniques and found that the efficiency rate was $92 \%$. The current results agree with Renneker $e t$ al. (10) who found that the infection rate of A. ovis in sheep of the northern areas of Iraq was $62.6 \%$. In another study that uses PCR, Soosaraeia et al. (28) and Yousefi et al. (18) found that sheep and sheep and goat were infected with $A$. 
marginale and $A$. ovis respectively in Iran, and Ghaffar et al. (29) found A. marginale in small ruminants in Pakistan, and this agrees with the current study results. The current study results also agree with Ayyz et al. (15), Al-Kassar et al. (16) and Naqid et al. (17) who detected infection of this infectious agent in sheep, goat and cattle in Al-Qadisiyah province, Al-Nasiriyah city, Duhok province, Iraq. The study identifies $A$. marginale as a member of infectious agents that affect sheep in the study province.

\section{Conclusion}

To investigate the spp. of Anaplasma in sheep in AlDiwaniyah province, Iraq. We collect 50 blood samples for Molecular identification of Anaplasma marginale between sheep. The results have shown that 8 blood samples were infected with A. marginale. The PCR-based identification has revealed a confirmative identification of the Anaplasma marginale in the infected sheep.

\section{Acknowledgments}

The authors thank Professor Jabbar A. Alssady Dean of College of Veterinary Medicine, University of AlQadisiyah, Iraq, for technical assistance.

\section{Conflict of interests}

The authors have not received any funding or benefits from industry, agency of financing, or elsewhere to conduct this study.

\section{References}

1. Cangussu ASR, Mariuba LAM, Lalwani P, Pereira KDES, AstolphiFilho S, Orlandi, PP, Epiphanio S, Viana KF, Ribeiro MFB, Silva HM, Marinho CRF, Nogueira PA. A hybrid protein containing MSP1a repeats and Omp7, Omp8 and Omp9 epitopes protect immunized BALB/c mice against anaplasmosis. Vet Res. 2018;49:6. DOI: 10.1186/s13567-018-0503-4

2. Qiu H, Kelly PJ, Zhang J, Luo Q, Yang Y, Mao Y, Yang Z, Li J, Wu $\mathrm{H}$, Wang C. Molecular Detection of Anaplasma spp. and Ehrlichia spp. in Ruminants from Twelve Provinces of China. Canadian J Infect Dis Med Microbiol. 2016;16(1):1-9. DOI: $10.1155 / 2016 / 9183861$

3. Kocan KM, De Fuente J, Alberto A, Meléndez RD, Fuente D, Guglielmone A, Mele, RD. Antigens and alternatives for control of Anaplasma marginale infection in cattle. Clin Microbiol Rev. 2003;16:698-712. DOI: 10.1128/CMR.16.4.698-712.2003

4. Kocan KM, De Fuente J, Blouin EF, Coetzee JF, Erwing SA. The natural history of Anaplasma marginale. Vet Parasitol. 2010;167:95107. DOI: $10.1016 /$ j.vetpar.2009.09.012

5. Kuttler K. Anaplasma infections in wild and domestic ruminants: a review. J wildlife Dis. ses. 1984;20:12-20. DOI: 10.7589/0090-3558$\underline{20.1 .12}$

6. Aubry P, Geale DW. A review of bovine anaplasmosis. Transbound Emerg Dis. 2011;58:1-30. DOI: 10.1111/j.1865-1682.2010.01173.x

7. Woldehiwet Z. The natural history of Anaplasma phagocytophilum. Vet Parasitol. 2009;167:108-122. DOI: $\underline{\text { 10.1016/j.vetpar.2009.09.013 }}$
8. Palmer GH, Rurangirwa FR, Kocan KM, Brown WC. Molecular basis for vaccine development against the ehrlichial pathogen Anaplasma marginale. Parasitol Today. 1999;15:281-286. DOI: 10.1016/S01694758(99)01469-6

9. Ben SM, Belkahia H, Alberti A, Zobba R, Bousrih M, Yahiaoui M, Daaloul-Jedidi M, Mamlouk A, Gharbi M, Messadi L. Molecular survey of Anaplasma species in small ruminants reveals the presence of novel strains closely related to A. phagocytophilum in Tunisia. Vect Borne Zoonot Dis. 2015;15:580-590. DOI: 10.1089/vbz.2015.1796

10. Jaswal H, Bal M, Singla L, Gupta K, Brar A. Pathological observations on clinical Anaplasma marginale infection in cattle. J Parasit Dis. 2015;39:495-498. DOI: 10.1007/s12639-013-0384-4

11. Renneker S, Abdo J, Bakheit MA, Kullmann B, Beyer D, Ahmed J, Seitzer U. Coinfection of sheep with Anaplasma, Theileria and Babesia species in the Kurdistan Region, Iraq. Transb Emerg Dis. 2013;2:113-8. DOI: 10.1111/tbed.12148

12. ALfatlawi MAA, Ali M, Naser H. Molecular identification of allelic genotypes of pyrethroid-insecticide resistance in housefly, Iraq. Iraqi J Vet Sci. 2019;33(2):209-212. DOI: 10.33899/ijvs.2019.125538.1060

13. Saeed ZK, Abbas BA, Othman RM. Molecular identification and phylogenetic analysis of lactic acid bacteria isolated from goat raw milk. Iraqi J Vet Sci. 2020;34(2):259-263. DOI: 10.33899/ijvs.2019.125896.1176

14. Al-Fatlawi MA, Ali MJ, Albayati HH. Morphological and phylogenetic study of Hyalomma anatolicum in Al-Najaf, Iraq. Iraqi J Vet Med Sci. 2018;32(2):261-266. DOI:10.33899/ijvs.2019.153860.

15. Ayyz HN, Khudhir YI, Kshah KH. Molecular detection and phylogenetic analysis of Anaplasma spp. in cattle in Al-Qadisiyah province of Iraq. Mac Vet Rev, 2019;42(2):181-188. DOI: 10.2478/macvetrev-2019-0023

16. Al-Kassar NR, Flayyih MM, Al-Jorany AD. Molecular study of Anaplasma marginale parasite in carrier cattle in Al-Nasiriyah city. Iraqi $J$ of Vet Med Sci, 2018;32(2):299-301. DOI: 10.33899/ijvs.2019.153867.

17. Naqid IA. Prevalence of Anaplasma ovis infection in Angora goats of Duhok province, Kurdistan Region-Iraq. Iraqi J Vet Med Sci, 2017;31(2):73-79. DOI: 10.33899 /ijvs.2017.145599

18. Yousefi A, Rahbari S, Shayan P, Sadeghi-dehkordi Z, Bahonar A. Molecular detection of Anaplasma marginale and Anaplasma ovis in sheep and goat in west highland pasture of Iran. Asian Pacific J Trop Biomed. 2017;7(5):455-459. DOI: 10.1016/j.apjtb.2017.01.017

19. Hussain M, Junaid A, Gul R, Jamal MA, Ahmed I, Talpur MZ, Rahim K, Fatima M, Munir S. First detection on prevalence of Anaplasma marginale in sheep and goat in Karak District, Pakistan. Asian Pacific J Trop Dis. 2017;7(9):531-539. DOI: 10.12980/apjtd.7.2017D7-89

20. Lacasta D, Ferrer LM, Sanz S, Labanda R, Gonzalez JM, Benito AA, Ruiz H, Rodriguez-Largo A, Ramos JJ. Anaplasmosis outbreak in lambs: First report causing carcass condemnation. Animal. 2020;10(2):1851. DOI: 10.3390/ani10101851

21. Eisawi NM, El Hussein ARM, Hassan DA, Musa AB, Hussien MO, Enan KA, Bakheit MA. A molecular prevalence survey on Anaplasma infection among domestic ruminants in Khartoum State, Sudan. Trop Animal Heal Product. 2020;52(4):1845-1852. DOI: 10.1007/s11250019-02176-7

22. Al-Hosary A, Raileanu C, Tauchmann C, Fischer S, Nijhof AM Silaghi C. Epidemiology and genotyping of Anaplasma marginale and co-infection with piroplasms and other Anaplasma taceae in cattle and buffaloes from Egypt. Parasit Vect. 2020;13(1):495-500. DOI: 10.1186/s13071-020-04372-Z

23. Alfatlawi MAA, Jasim AA, Jarad NE, Khlaif SF. Clinical and molecular identification of ruling Theileria annulata strains in cattle calves in Al-Diwaniyah province, Iraq. Iraqi $J$ Vet Sci. 2021;35(1):115-119. DOI: 10.33899/ijvs.2020.126429.1319

24. Ali MJ, Karawan AC, Al-Fetly DR, Al-fatlawi MAA. Synergizing the deltamethrin larvicidal activity against Aedes albopictus larvae using cinnamaldehyde in Diwaniyah, Iraq. Iraqi J Vet Sci. 2020; 34(2):317320. DOI: $10.33899 /$ ijvs.2019.126026.1212

25. Da Silva NB, Taus NS, Johnson WC, Mira A, Schnittger L, Valente JDM, Vidotto O, Masterson HE, Vieira TSWJ, Ueti MW, Vieira RFC. 
First report of Anaplasma marginale infection in goats, Brazil. PLOS One. 2018;13(8):1-6. 10.1371/journal.pone.0202140

26. Peng Y, Wang K, Zhao S, Yan Y, Wang H, Jing J, Jian F, Wang R, Zhang L, Ning C. Detection and phylogenetic characterization of Anaplasma capra: An emerging pathogen in sheep and goats in China. Cell Infect Microbiol. 2018;8(1):238. DOI: 10.3389/fcimb.2018.00283

27. Gale KR, Dimmock CM, Gartside M, Leatch G. Anaplasma marginale: detection of carrier cattle by PCR-ELISA. Inter J Parasitol. 1996;26(10):1103-9. DOI: 10.1016/S0020-7519(96)80009-9

28. Soosaraeia M, Haghi MM, Etemadifar F, Fakhar M, Teshnizi SH, Asfaram S, Esboeie BR. Status of Anaplasma spp. infection in domestic ruminants from Iran: A systematic review with metaanalysis. Parasit Epidemiol Cont. 2020; 11(1):e00173. DOI: 10.1016/j.parepi.2020.e00173

29. Ghaffar A, Ijaz M, Ali A, Farooqi SH, Rehman A, Ali MM, Zafar MZ, Naeem MA. First report on molecular characterization of Anaplasmosis in small ruminants in Pakistan. J Parasitol, 2020;106(3):360-368. DOI: 10.1645/19-90.

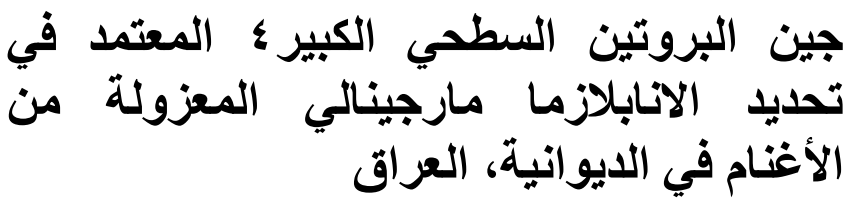

صبا فلاح كليف'، اسعد جاسم، منير عبد الأمير القتلاوي بّ و منصور جدعان عليّ

'وحدة بحوث الأمراض المشتركة، ‘فرع الطب الباطني والوقائي،

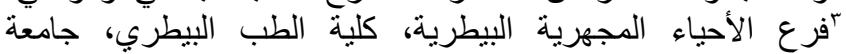

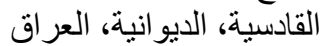

الخلاصة

إن الغرض من هذه الدراسة هو لتحديد أنواع الانبلازما في الأغنام

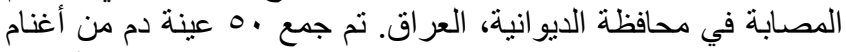

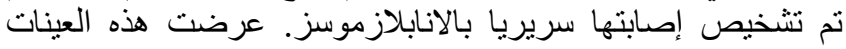
لاستخلاص الحامض النووي منقوص الاوكسجين منبو عا باختبار

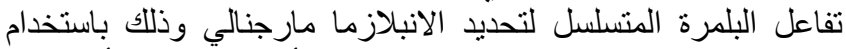

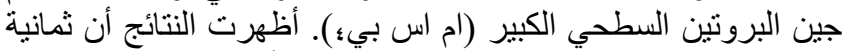
عينات كانت مصابة بالانبلازما مارجنالي. أظهرت الثرت نتائج التحديد

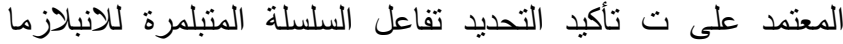

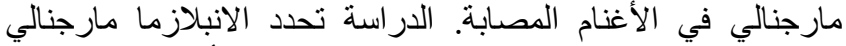
كعضو من العوامل الخمجية التي تؤثر على الأغنام في المدينة

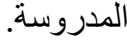

